\title{
Defence mechanisms during intestinal infection
}

\author{
ANDRÉ BURET, LIC.ÈS SC, MSC
}

A BURET. Defence mechanisms during intestinal infection. Can J Gastroenterol 1991;5(1):34-42. This review examines and compares host defence mechanisms during intestinal infection with three types of organisms: a virus, a bacterium and a nematode parasite (ie, transmissible gastroenteritis virus [TGEV], Helicobacter jejuni and Trichinella spiralis). Diarrhea is commonly associated with all of these infections. It appears that $T$ spiralis initiates the most elaborate defence system of the three organisms, involving full range humoral and cellular immunity, as well as mucus hypersecretion, epithelial alterations, altered gut motility and parasite impairment (morphological and physiological). In contrast, intestinal defence against $H$ jejuni and TGEV involves fewer components. The latter seems to initiate the most rudimentary host response. Despite such differences, these mechanisms exhibit many similarities, thus further illustrating the relatively limited repertoire of defence systems that the intestine can mount. The mediators translating the insult of any intestinal pathogen into a common response deserve further investigation.

Key Words: Intestinal defence, Pathophysiology

\section{Mécanismes de défense à l'oeuvre durant les infections intestinales}

RESUME: Le présent article examine et compare les mécanismes de défense intervenant lors d'infections intestinales dues à trois types d'organisme: un virus, une bactérie et un nématode (Virus des gastroentérites transmissibles, Campylobacter jejuni et Trichinella spiralis). La diarrhée est communément associée avec ces trois infections. Il semble que $T$. spiralis déclenche le système immunitaire le plus complexe, monopolisant toute la gamme des composantes humorales et cellulaires et entraînant également une hypersécrétion de mucus, des altérations épithéliales, des modification du transit intestinal et des troubles dus à la présence du parasite (morphologiques et physiologiques). En comparaison, la défense intestinale que provoquent $C$. jejuni et le virus des gastroentérites transmissibles mobilise un nombre moindre d'éléments. Ce dernier virus semble provoquer la réponse la plus rudimentaire. Malgré ce qui les distingue, ces mécanismes manifestent de nombreuses similarités et illustrent ainsi le répertoire immunitaire relativement limité de l'intestin. Les médiateurs qui transforment l'agression de tout pathogène intestinal en réaction commune méritent une étude plus approfondie.

Department of Biological Sciences, University of Calgary, Calgary, Alberta

Correspondence and reprints: Dr André Buret, Department of Biological Sciences, University of Calgary, Biosciences 055, 2500 University Drive NW, Calgary, Alberta T2N IN4. Telephone (403) 220-5279

Received for publication April 24, 1990. Accepted October 1, 1990
W HEN INFECTED WITH VIRAL bacterial, protozoal or helminthic organisms, a host is confronted with a wide spectrum of morphological, biochemical and antigenic features. Despite the tremendous diversity of antigenic stimuli, there are nevertheless striking similarities in host response mechanisms. This is in part due to the relatively limited repertoire of defence systems that the host can mount, despite its enormous complexity. By far, the most common parasitic diseases are those affecting the gastrointestinal sys. tem (1). This review describes and compares, when information is available, host defence mechanisms against gastrointestinal infections caused by viral, bacterial and nematode organisms, ie, transmissible gastroenteritis virus (TGEV), Helicobacter jejuni (formerly Campylobacter) and Trichinella spiralis, all three common pathogens in swine (2). Viral gastroenteritis was recently identified as an intestinal disorder of major sig. nificance in humans (3), but the pathogenesis of such disturbances is not well understood. In contrast, more information is available on TGEV in swine (4). H jejuni is recognized as one of the most common causes of human diarrhea worldwide $(5,6)$. This bacterium is also present in wild birds, chickens, swine, sheep, cattle and other animals (2) and, in view of the numerous reports of human infection acquired from both dogs and cats, there is little doubt regarding the zoonotic 
potential of this infection (7). It has been demonstrated that this invasive enteropathogenic bacterium produces a cholera-like toxin which activates adenylate cyclase (8), but recent evidence suggests that enterotoxin does not play a major role in the pathogenesis of $H$ jejuni infections in the United States (9). Finally, gastrointestinal nematodiasis in domestic animals and humans is an infection of worldwide distribution and major economic significance. One of the most popular models for the study of this type of infection has been the gastrointestinal phase of T spiralis (10).

Diarrhea is commonly associated with all of the infections mentioned above. Obviously, the cleansing action resulting from this gastrointestinal flushing is an important host defence mechanism in these diseases, but to review the pathophysiology of diarrhea is beyond the scope of the present review.

By focusing on three types of gastrointestinal infection (ie, viral, bacterial and parasitic), the aims of this review are: to describe immunological and nonimmunological mucosal responses to acute intestinal infection; and to identify the similarities and differences in host defences during a variety of intestinal insults.

There is no doubt that the host immune system is involved in the protective response against TGEV, H jejuni and $T$ spiralis. It will be demonstrated further that the degree of this involvement varies from one type of infection to the other. For the sake of clarity, and although antibody-mediated and cellular immunity are inextricably linked, they will be addressed separately in this review.

\section{TGEV}

Humoral immunity: In transmissible gastroenteritis, passive immunity can be transferred to piglets via ingestion of immune colostrum and milk containing high neutralizing antibody titres $(11,12)$. Active production of antibodies to TGEV has also been documented (13). Sows inoculated with TGEV have been shown to develop neutralizing antibodies for the virus in serum ( $\operatorname{IgM}, \operatorname{IgG}$ and $\operatorname{Ig} A)$, colostrum (primarily IgG) and milk (primarily $\operatorname{IgA})(14,15)$. However, the mechanisms of active immunity in transmissible gastroenteritis remain poorly understood. Although young pigs that have recovered from transmissible gastroenteritis usually resist reinfection (16), it is well documented that circulating antibodies provide little protection against subsequent challenge by the virus $(12,15,17)$. Thus, serum antibodies produced in this infection do not appear to correlate with immunity to this disease. Furthermore, while secretory $\operatorname{Ig} \mathrm{A}$ in intestinal secretions may protect the mucosa from infection, anti-TGEV antibodies are not always detectable in gut contents from infected animals (16). Interestingly, coronavirus enteritis in dogs appears to initiate an immune response similar to that just described for TGEV in swine, and there is an antigenic relationship between both viral agents (18). In addition, the two organisms are serologically cross-reactive (14). Experiments involving inoculation of TGEV into dogs have failed to protect these dogs from canine coronavirus, and similarly, pigs could not be protected from TGEV with canine coronavirus $(14,18)$.

Cellular immunity: As mentioned above, production of local and circulating antibodies in pigs infected with TGEV do not satisfactorily explain active immunity against this disease. In contrast, local cell-mediated immunity in the small intestine appears to play a major role in active immunity to transmissible gastroenteritis. The presence of antigen-reactive cells in Peyer's patches during all stages of the infection demonstrated that Peyer's patches participate directly in the immune response against this virus, rather than serving only as a site of differentiation for immunoblasts (19). The same study clearly showed the occurrence of cellmediated immunity in transmissible gastroenteritis, and demonstrated that cytotoxic $T$ cells were involved more than $B$ cells both in recovery from a primary infection and in protection of immune pigs (19). The participation of interferon as yet another line of local defence has also been questioned. It was demonstrated that transmissible gastroenteritis leads to significant interferon production in the lumen and mucosa, but that it has no discernible protective effect of its own (20). High interferon activities have been measured in lymphocyte and macrophage cultures where controlled or inhibited viral replication was observed (21). The type of interferon was not defined in these reports. These findings suggest that while interferon activity on its own does not protect the host from transmissible gastroenteritis, it may mediate antiviral cytotoxicity. A similar defence mechanism has been recently described in bacterial infections (22) and toxoplasmosis (23).

During transmissible gastroenteritis, the lamina propria is infiltrated with mononuclear cells, neutrophils and eosinophils (24). However, the inflammation is discrete (24), and no striking cellular infiltrate other than the lymphocyte proliferative response has yet been associated with the infection (16). In vitro studies showed that macrophages have the ability to control the intracellular replication of TGEV without killing it (21). Other authors reported that the virus could be recovered from the lungs of oronasally infected pigs 104 days post inoculation, and that the virus was capable of replicating in alveolar macrophages (25), thus suggesting that this organism may be maintained alive in the lymphatic system for an extended period.

Epithelial alterations: Villous atrophy and fusion and/or epithelial sloughing are commonly associated with transmissible gastroenteritis $(15,26)$ as well as with $H$ jejuni $(27), T$ spiralis $(28,29)$ and other intestinal infections. A decrease in surface area exposed to the pathogen results from these alterations, and thus this mechanism can be considered a host defence mechanism against gastrointestinal disease.

Pathogen impairment: Any biochemi$\mathrm{cal}$, morphological or other damage incurred to a virulent TGEV from its exposure to the intestinal environment has yet to be described. It was demonstrated, however, that luminal proteases and peptidases greatly reduced infectivity of attenuated 
TGEV virus, whereas they did not inactivate a virulent virus (30). This reiterated the important role of pancreatic and mucosal secretions in intestinal protection. It also substantiated the notion of differential susceptibility to small intestinal secretions as a correlate of virulence.

\section{H JEJUNI}

Humoral immunity: In contrast with transmissible gastroenteritis, infection with $H$ jejuni results in development of specific serum IgG, IgM and IgA, which confer immunity to subsequent challenge (31-33). People who have had multiple exposures to this bacterium exhibit persistently elevated anti- $\mathrm{H}$ jejuni IgG titres associated with little or no illness (34). High titres of anti-H jejuni intestinal $\operatorname{IgA}$ reported in rabbits orogastrically inoculated with the organism suggested that mucosal $\operatorname{Ig} \mathrm{A}$ also plays an important role in antihelicobacter immunity (31). In another study, an age-related increase in antihelicobacter serum IgA titres was noted among children living in endemic areas, and this appeared to be the best indicator of anti-helicobacter immunity $(35,36)$. In addition, individuals with documented $\operatorname{Ig}$ A immunodeficiencies have frequently been reported to have difficulty recovering from $\mathrm{H}$ jejuni enteritis (37). All of these findings strongly suggest that serum $\operatorname{IgG}$ and $\operatorname{Ig} A$, and intestinal $\operatorname{IgA}$ are the major antibody components of defence against this microorganism.

Cellular immunity: Human studies (38), as well as animal models $(27,32,39)$, have demonstrated that tissue inflammation in $\mathrm{H}$ jejuni infections is characterized by infiltration of the mucosa with neutrophils. The inflammatory infiltrate also revealed increased numbers of mononuclear cells, eosinophils, plasma cells and undefined lymphocytes $(32,38,39)$. Diffuse infiltration of the lamina propria with mature plasma cells and undefined lymphocytes has been demonstrated in $\mathrm{H}$ jejuni infections (32). Another study showed that the major antibody-secreting cell detected in patients suffering from acute $H$ jejuni diarrhea were $\operatorname{IgA}$ - producing cells, thus further implying that a strong $B$ cell response was associated with this infection (40). In other bacterial infections, $\mathrm{T}$ cells have been shown to be potent down- or upregulators of antigen-stimulated B cells, thus controlling the amount of antibody production (41). However, the exact nature of the interaction between $\mathrm{T}$ and $\mathrm{B}$ cells during $H$ jejuni infections has not yet been defined. Results from a study where $H$ jejuni enhanced natural killer cell activity in athymic nude mice, but suppressed natural killer cell activity in heterozygous mice, suggest that natural killer cell activity has little importance in defending an immunocompetent host (42).

Membranous epithelial cells (M cells) lining the dome of Peyer's patches are involved in antigenic transport from the lumen towards the underlying lymphoid cells and thus play an important role in mucosal immunity (43). M cells have been shown to transport microorganisms such as viruses (44), bacteria (45) and some protozoa (46). No information is yet available on the possible interaction of TGEV and T spiralis antigens with $\mathrm{M}$ cells. In contrast, there is evidence to suggest that the host response to $H$ jejuni involves $\mathrm{M}$ cells, to which these bacteria adhere selectively (47). Although this mechanism results in phagocytosis of some of the organisms, it may also provide a route for systemic spread. The net effect on the bacteria and/or on the host of $\mathrm{H}$ jejuni translocation by $M$ cells remains unclear.

Mucus: Reports on $H$ jejuni infections are in direct contrast with the common observation of goblet cell hyperplasia during other intestinal infections. $\mathrm{Al}$ though it was suggested that $H$ jejuni chemotaxis toward mucus may be an important factor in the affinity of the organism for the intestinal tract (48), this bacterial infection does not appear to induce goblet cell proliferation. On the contrary, there is evidence to suggest that goblet cell numbers are decreased in $H$ jejuni infections (32). As a result, it seems that the protective role of mucus is inhibited by the bacterium. The mechanism by which this organism manages to evade and/or interfere with the host's production of protective mucus has not yet been elucidated.

Epithelial alterations: As mentioned above, villous atrophy is a common finding during $\mathrm{H}$ jejuni infections (27). Moreover, the epithelial cell sloughing often observed in these infections allows elimination of infected enterocytes into the lumen.

Altered intestinal motility: Altered gut motility has been observed during $\mathrm{H}$ jejuni infections. Increases in repetitive bursts of action potentials have been demonstrated in segments of isolated rabbit ileum exposed to the cell-free supernatant of a culture of $H$ jejuni (49). The effect of these disturbances on intestinal peristalsis and transit and their potential for eliminating the pathogen remain unknown.

Pathogen impairment: There is evidence to suggest that protection against enteric colonization by $\mathrm{H}$ jejuni may be mediated by in vivo production of antibodies to the bacteria's flagella (50). The polar flagellum carried by $H$ jejuni seems to be an important virulence factor involved in epithelial adhesion (51). Aflagellate bacteria are unable to colonize the intestinal tract (52), and flagellin-specific antibodies appear to provide some protection against intestinal colonization (53). Hence, in vivo production of an antibody against the flagellum of $H$ jejuni may impair bac. terial motility and adhesion, and thus protect the host from infection.

\section{T SPIRALIS}

Humoral immunity: Immune exclusion is particularly striking in trichinosis and is clearly demonstrated by the mechanism of rapid expulsion in immune animals (54). Rapid expulsion requires specific systemic immunity and a local enteric response in order to reach its full expression (55). It has been suggested that immune exclusion is the main component of rapid expulsion of $T$ spiralis parasites (54). It has also been shown that rats infected with $T$ spiralis larvae develop a strong immunity to larval reinfection even though they are not resistant to infection with adult worms (55). Another antibody isotype, $\operatorname{IgE}$, appears to be involved in host defence against 
trichinosis $(56,57)$. $\mathrm{IgE}$ is the antibody isotype most commonly associated with anaphylactic-like reactions. One function of anaphylactic antibodies, described for tissue migrating parasites, is the promotion of antibody-dependent killing of nematodes by macrophages and granulocytes (58). Such mechanisms have been described in vitro and may be effective against the larval migratory phase of $T$ spiralis (56), but there is no evidence that they operate against the adult worms in the gut. Anaphylactic antibodies are most likely to be involved in the reactions which expel worms from immune animals, since mast cell numbers are greatly increased in nematode infections, as will be seen further. Incidentally, this mechanism, characteristic of trichinosis but not of TGEV and $H$ jejuni infections, is the basis for the IgEmediated anaphylactic pathology of the infected intestine in trichinosis (57).

Cellular immunity: There is evidence to suggest that part of the host protective response against $T$ spiralis involves an active reduction of fecundity of the parasite (54). It was demonstrated that the transfer of immune mesenteric lymph node cells from an infected donor mouse to irradiated infected mice could reduce the fecundity of the worms, thus suggesting that this mechanism may be immune-mediated (59). However, these findings were in contradiction with a previous study in which similar experimental conditions in rats failed to demonstrate a reduction in worm fecundity $(60)$. Whether such adiscrepancy reflects a species-dependent factor or another experimental component remains unanswered. Still other studies have demonstrated that injection of thoracic duct lymphocytes obtained from immune rats could protect normal rats against $T$ spiralis challenge (61). These immune cells increased the rate of expulsion of adult worms from the small intestine. Successful transfer of resistance against trichinosis has also been accomplished in mice via injection of lymph node cells obtained from immune hosts (62). Prolonged infection reported in athymic mice further indicated the important mediating potential of $\mathrm{T}$ cells in the adaptive immune response against this nematode (62). In yet another study, injection of B cell-enriched thoracic duct lymphocytes provided strong resistance against trichinosis in rats, and the protection was totally inhibited if these cells were treated with a mitotic inhibitor prior to inoculation (63). From these observations, it appeared that acquired resistance to $T$ spiralis is mediated by both of the major classes of lymphocytes, ie, T and B cells. The above findings imply that immune $\mathrm{T}$ cells have a helper function in promoting the formation of protective $B$ cells during $T$ spiralis infection.

Eosinophils and mast cells are without question the most prominent components of the cellular reaction to $T$ spiralis infection $(54,64)$. Eosinophils are typically observed in the lamina propria as well as within the tissue granulomas surrounding the nematodes (64). In vitro experiments demonstrated that eosinophilic granule proteins efficiently killed $T$ spiralis larvae (65). In contrast with TGEV and $H$ jejuni infections, colonization of the gastrointestinal tract by $T$ spiralis and other nematodes is associated with mucosal mastocytosis, which is a thymus-dependent mechanism in parasitized rats $(66,67)$. Although these cells possess the necessary 'tools' to inflict damage, they do not appear to be involved in direct killing of the nematodes $(67,68)$. In the rat, mucosal mast cells secrete a distinct protease, rat mucosal mast cell protease II (RMCP II), which can be detected in the circulation (69). In rats infected with $T$ spiralis, systemic secretion of RMCP II coincides with expulsion of the adult worms (66). Such findings clearly demonstrate that mucosal mast cells are functionally active during the immune elimination of primary $T$ spiralis infections. It was demonstrated that mast cells would adhere to larvae prior to eosinophil adherence in the process of eosinophil-dependent killing of $T$ spiralis (67). Mast cells and eosinophils have been described as active partners in parasite killing (70). The same authors also demonstrated that this mechanism was $\operatorname{lgE}$-dependent (70). These associations clearly suggest that mast cells influence eosinophils in the killing of parasites during secondary $T$ spiralis infections. The possible mediators involved in this cooperation remain unknown. Yet another possible host defence mechanism involving mast cells occurs via the mediators that they release. Serotonin and histamine have been identified as mediators in the release of mucus from epithelial tissue $(71,72)$. Thus, the potential for host defence becomes obvious if mast cellreleased histamine and serotonin actively initiates mucus secretion in vivo during parasitic infection, which remains to be demonstrated. Mast cells can also release vasoactive intestinal polypeptide (VIP) (73). VIP is a potent inducer of cyclic AMP-mediated water and electrolyte secretion in the intes. tine (74). Since mast cells are activated in $T$ spiralis infection, one can postulate that VIP may be released during $\operatorname{lgE}$ mediated reactions in the immune host. This in turn would result in intestinal secretion and thus possibly help the host to eliminate the parasite. Clearly, the fascinating involvement of mast cells during intestinal infections deserves further investigation.

Mucus: When parasites and other organisms enter the gastrointestinal lumen, they inevitably come in contact with the superficial mucus layer, a complex mixture of mucin glycoproteins covering the epithelium. That mucus could be involved in protection against parasites is inferred from numerous histological observations of goblet cell hyperplasia associated with infection. The excretion of mucus provides the host with a nonspecific defence mechanism, both as a physical barrier and by its continuous cleansing action, which helps to sweep microorganisms towards the villus tip and downstream in the lumen (75). Obviously, the limited volume of flow along a villus $(2 \mu \mathrm{L} /$ day $)$ is not sufficient to prevent all microorganisms from colonizing this area (75), but mucus has more powerful means of protecting the host from parasites. Mucus-mediated protection against $T$ spiralis involves the immune system of the host, clearly illustrating the complex intricacies of the immunological and nonimmunological host responses 


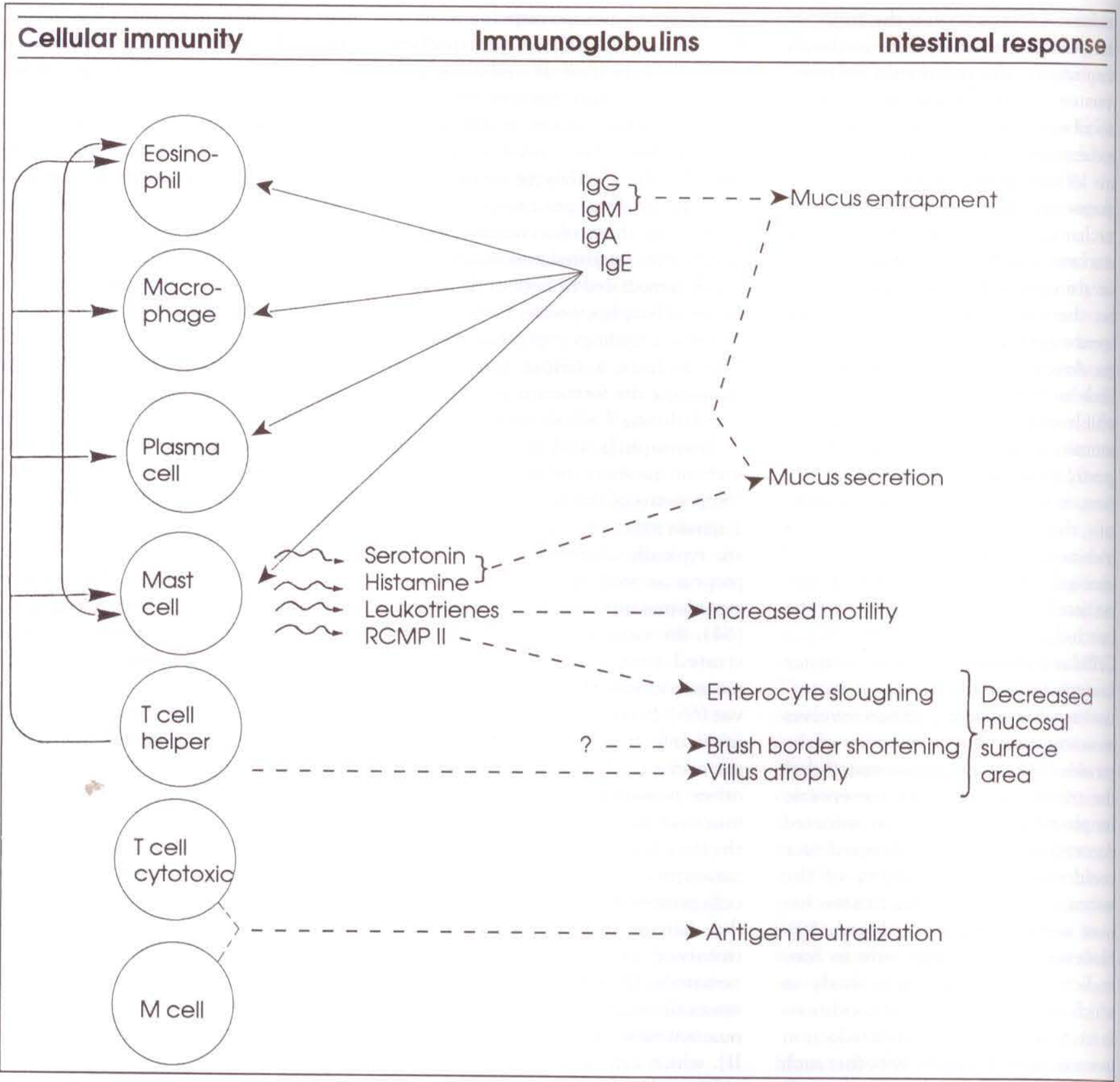

Figure 1) Overview of the main interactions leading to the five major types of intestinal defence systems discussed in this review. Rather than attempting to be all encompassing, this chart illustrates the central role mucosal mast cells may play in intestinal defence against infection. Solid arrows Interaction of immune and nonimmune elements; Broken arrows Initiation of enteric response; Wavy arrows Release of cytokines or other products

to disease. The important role of mucus in the trapping and exclusion of $T$ spiralis has been well documented $(54,76)$. An association of goblet cell hyperplasia with the onset of worm expulsion has been recorded in rats and mice infected with the nematode (77). It was observed that during rapid expulsion, the larvae failed to penetrate the epithelium (78,79). At the time of this infection, $T$ spiralis appeared to be trapped within the mucus layer (78).
This experiment also demonstrated the significant role of parasite-specific immunoglobulins in the physical entrapment of nematodes within the mucus layer. Larvae were sensitized with immune and nonimmune serum or bile and then carefully mixed with mucus from immune and nonimmune rats. Bile failed to promote any mucus trapping as did serum from native rats, whereas significant trapping occurred when the organisms had been exposed to immune serum; no difference between immune and nonimmune mucus was observed in this process (78). Rapid expulsion of $T$ spiralis can be blocked by pretreating immune rats with cortico. steroids (80), thus further illustrating the significance of immune involvement in this process. From these results, it was suggested that parasite-specific immunoglobulins, but not $\operatorname{IgA}$, were essential components of the process of $T$ spiralis mucus trapping. Such findings 
TABLE

Summary of the host defence mechanisms involved in self-protection against three pathogens

\begin{tabular}{|c|c|c|c|c|}
\hline & TGEV & $\begin{array}{c}\text { Helicobacter } \\
\text { jejuni }\end{array}$ & $\begin{array}{c}\text { Trichinella } \\
\text { spiralis }\end{array}$ & References \\
\hline \multicolumn{5}{|l|}{ Immune responses } \\
\hline Circulating antibodies & +- & + & + & $14,15,32,33,35,55$ \\
\hline $\lg E$ & $-?$ & $-?$ & + & 56,57 \\
\hline Mucosal IgA & +- & + & + & $16,31,55$ \\
\hline T cells & + & $+?$ & + & $19,41,62$ \\
\hline$B$ cells & +- & + & + & $19,40,41,63$ \\
\hline Mcells & ND & $+?$ & ND & 47 \\
\hline Natural killer cells & ND & - & ND & 42 \\
\hline Neutrophils & +- & + & +- & $24,27,32,38,39,64$ \\
\hline Monocytes & + & +- & +- & $21,24,32,38,39,64$ \\
\hline Eosinophils & +- & +- & + & $24,32,38,39,64$ \\
\hline Mast cells & $-?$ & $-?$ & + & $54,64,66$ \\
\hline Paneth cells & ND & ND & ND & \\
\hline \multicolumn{5}{|l|}{ Nonimmune responses } \\
\hline Mucus & ND & - & + & $32,54,76,77$ \\
\hline Epithelial alterations & + & + & + & $15,26-29,81,86$ \\
\hline Altered gut motility & ND & $+?$ & + & $49,79,87$ \\
\hline Parasite impairment & $-?$ & + & + & $51,53,54,61$ \\
\hline
\end{tabular}

Despite the unquestionable intricacies of their involvement in host defence, immune and nonimmune responses were listed separately. Substantiating references are listed. TGEV Transmissible gastroenteritis virus; + Protective component of host defence; + - Factor involved in host defence, but to a lesser degree: - Factor not involved in host defence: ? Involvement (or noninvolvement) of a factor, postulated from related findings: ND No data available

leave little doubt about the potent barrier effect that mucus can have on the establishment of this nematode.

Epithelial alterations: In $T$ spiralis infection, villous atrophy and crypt hyperplasia have been shown to coincide with the expulsion of adult worms (81). In thymectomized mice, worm expulsion, villous atrophy and crypt hyperplasia were either reduced or absent (81), thus confirming previous studies which demonstrated that villous atrophy was $\mathrm{T}$ cell-mediated (82). This suggests that local cell-mediated responses are involved in both the pathogenesis of the lesions and the expulsion of the parasite.

Loss of brush border microvillous surface area has been associated with many gastrointestinal diseases (83). Yersiniosis (84) and giardiasis (85) both result in a diffuse reduction of brush border surface area in the host's small intestine. It is possible that this common mechanism is yet another component of the complex host defence system against intestinal insult, exposing less mucosal surface area to a pathogen and its antigen(s). It appears that this morphological alteration can be coupled with a biochemical change in the brush border. Indeed, intestinal brush border from immune rats previously exposed to $T$ spiralis had a persistent, lower binding capacity for wheat germ agglutinin than normal microvilli from control rats (86). Whether biochemical alterations to brush borders may disorient microorganisms and prevent their invasion or attachment to enteric epithelial cells remains to be answered.

Altered intestinal motility: Altered gut motility has been reported during $T$ spiralis infections. Significantly increased intestinal transit was demonstrated in primary infections $(79,87)$ but not following a secondary challenge (79). It has been suggested that corticosteroids may be responsible for the inhibited response observed in immune rats (54), via a mechanism where corticosteroids would inhibit mast cell synthesis of leukotriene, a potent smooth muscle stimulator (88). The effect of altered small bowel propulsion on parasite development and/or expulsion remains to be clarified.
Pathogen impairment: Reduced fecundity of $T$ spiralis resulting from hostparasite interactions (54) and morphological damage to adult worms (61) have been reported as potentially important host defence components against trichinosis. However, damaged worms seem to recover and survive as effectively as undamaged worms (55). Hence, the significance of these injuries remains unclear.

\section{SUMMARY AND CONCLUSIONS}

The findings reviewed above clearly illustrate the significant role played by humoral and mucosal antibodymediated host defence in immunity to $H$ jejuni and $T$ spiralis. While it is virtually beyond dispute that passive immunity to TGEV can be conferred on the young via immune milk, the significance of specific anti-TGEV antibodies in active immunity to this disease is still poorly understood. The mechanisms by which lymphocytes promote defence against a pathogen appear to differ during the three types of infection discussed here. During transmissible gastroenteritis, the major $\mathrm{T}$ cell-dependent host defence mechanism seems to follow the cytotoxic route, where a killer $T$ cell recognizes antigen on the surface of a virus-infected cell and responds by killing the target cell. Helper T cells may also be involved in host defence against the virus via macrophage activation. The cytotoxic and phagocytic mechanisms observed in TGEV infection may be interferon-mediated.

The lymphocytic response during $H$ jejuni infections is still unclear, but B cells appear to be a major component in host defence against this disease. It remains to be shown whether this response involves a $T$ helper route similar to that seen in trichinosis, where a $T$ cell recognizes nematode antigens and responds by secreting lymphokines that stimulate B cells to mature and secrete antibodies.

While the clinical symptoms induced in the intestinal mucosa are similar in all three infections, the underlying inflammatory cellular responses are quite different. $H$ jejuni 
infections are characterized by neutrophilia, and trichinosis by eosinophilia and local mastocytosis. In both infections, lymphocytes, macrophages and plasma cells increase in numbers at the infected site. The cellular response to TGEV is not as well defined. However, while no striking cellular infiltrate seems to be associated with the infection, inflammatory cells activated during the disease appear to involve primarily lymphocytes and macrophages. Paneth cells are found within the epithelium, at the bottom of crypts. There is evidence to suggest that microbes that progress deep into crypts can be cleared from these areas by Paneth cells, which are capable of phagocytosing and degrading intestinal microorganisms $(89,90)$. The influence of these particular cells in controlling any of the three infections dealt within this review is not known at this time.

Another striking difference among the viral, bacterial and parasitic infec-

\section{REFERENCES}

1. McGregor IA. The significance of parasitit infections in terms of clinical disease: A personal view. Parasitology 1987;94:S159-78.

2. Jones TC, Hunt RD. Veterinary Pathology, 5th edn. Philadelphia: Lea \& Febiger, 1983:574-657.

3. Dolin R, Treanor JJ, Madore P. Novel agents of viral enteritis in humans. J Infect Dis 1987;155:365-76.

4. Bergeland ME, Henry SC. Infectious diarrheas of young pigs. In: Biehl LG, ed. Diagnosis and treatment of swine diseases. Vet Clin North Am 1982:4:389-400.

5. Mims CA. The Pathogenesis of Infectious Disease, 3rd edn. London: Academic Press, 1987:179-225.

6. Donowitz M, Welsh MJ. Regulation of mammalian small intestinal electrolyte secretion. In: Johnson LR, ed. Physiology of the Gastrointestinal Tract, 2nd edn, Vol II. New York: Raven Press. 1987:1351-88.

7. Scarlett Kranz JM. Potential and newly recognized pet-associated zoonoses. In: Kirk RW, ed. Current Veterinary Therapy. Philadelphia: WB Saunders Co, 1986:1087-91.

8. Klipstein FA, Engert RF. Immunological relationship of the $B$ subunits of Campylobacter jejuni and Escherichia coli heat-labile enterotoxins. Infect Immun 1985;48:629-33. tions reviewed in this paper is the mucous response to each of these pathogens. While little is known about the involvement of mucus secretion in defence against TGEV, it appears that $H$ jejuni infection does not elicit mucus hypersecretion. In contrast, mucus trapping, likely immunoglobulinmediated, plays an important role in intestinal defence against $T$ spiralis. Finally, while TGEV does not seem to be impaired morphologically or otherwise by its exposure to the intestinal environment, there is little doubt that such exposure can impair $\mathrm{H}$ jejuni and $T$ spiralis.

This review illustrates the many host factors contributing to the defence against TGEV, H jejuni and T spiralis. Table 1 summarizes the similarities and differences between the mechanisms a host will use for protection against these three pathogens. It certainly does not reflect the complex intricacies of host defence against microorganisms. It ap- pears, however, that the host response against $T$ spiralis is the most elaborate of the three examples studied in this review. As discussed earlier, the symp. toms associated with the three pathogens studied are very similar, and yet, as shown in Table 1, the cellular response to each organism may differ. Such evidence suggests that a variety of injurious agents may elicit a similar syndrome in the intestine via common mediators which remain to be identified. While mucosal mast cells appear to play a central role in the intestinal defence system (Figure 1), the association between immunopathology and protection deserves further investigation.

ACKNOWLEDGEMENTS: This work was supported by the Swiss National Scientific Research Foundation, the Natural Sciences and Engineering Research Council ofCanada, the Alberta Heritage Foundation for Medical Research and the Izaak Walton Killam Memorial Fund.
9. Prez-Perez GI, Cohn DL, Guerrant RL, Patton CM, Reller LB, Blaser MJ.

Clinical and immunological significance of cholera-like toxin and cytotoxin production by Campylobacter species in patients with acute inflammatory diarrhea in the USA. J Infect Dis 1989;160:460-8.

10. Castro GA, Bullick GR. Pathophysiology of the gastrointestinal phase. In: Campbell WC, ed. Trichinella and Trichinosis. New York: Plenum Press, 1983:209-40.

11. Saif LJ, Bohl EH. Passive immunity in transmissible gastroenteritis of swine: Immunoglobulin classes of milk antibodies after oral-intranasal inoculation of sows with a live low cell culture-passaged virus. Am J Vet Res $1979 ; 40: 115-7$

12. Haelterman EO. Lactogenic immunity to transmissible gastroenteritis of swine. J Am Vet Med Assoc 1965;147:1661.

13. Wesley R, Woods R, Kapke P. Antibody response in swine to individual transmissible gastroenteritis virus (TGEV) proteins. In: Lai MMC, Stohlman SA, eds. Coronaviruses. New York: Plenum Press, 1987:475-81.

14. Woods R, Wesley RD. Immune response in sows given transmissible gastroenteritis virus or canine coronavirus. Am J Vet Res 1986; $47: 1239-42$.

15. Saif LG, Bohl EH. Transmissible gastroenteritis. In: Leman AD, Straw B, Glock RD, Mangeling WL, Penny RHC, Scholl E, eds. Diseases of Swine, 6th edn. Ames: Iowa State University Press, 1986:255-73.

16. Welch SW, Saif LJ, Ram S. Cell-mediated immune response of suckling pigs inoculated with attenuated or virulent transmissible gastroenteritis virus. Am J Vet Res 1988;49:1228-34.

17. Hooper BE, Haelterman EO. Concepts of pathogenesis and passive immunity in transmissible gastroenteritis of swine. J Am Vet Med Assoc 1976;149:1580-6.

18. Moreau PM. Canine viral enteritis. Compend Cont Ed Pract Vet 1980;2:540-7.

19. Shimizu M, Shimizu Y. Lymphocyte proliferative response to viral antigen in pigs infected with transmissible gastroenteritis virus. Infect Immun 1979;23:239-43.

20. La Bonnardiere C, Laude H. High interferon titer in newborn pig intestine during experimentally induced viral enteritis. Infect Immun 1981;32:28-31.

21. Laude H, Charley B, La Bonnardiere C. Interactions of porcine enteric coronavirus TGEV with macrophages and lymphocytes. In: Rottier PJM, van der Zeijst BAM, Spaan WJM, eds. Molecular Biology and Pathogenesis of Coronaviruses. New York: Plenum 
Press, 1984:385-6.

22. Lindemann RA. Roles of interferon and cellular adhesion molecules in bacterial activation of human natural killer cells. Infect Immun 1989;57:1702-6.

23. McLeod R, Eisenhauer P, Mack D, Brown C, Filice G, Spitalny G. Immune responses associated with early survival after peroral infection with Toxoplasma gondii. J Immunol 1989;142:3247-55.

24. Gowen AL, DeBuyssher EV. Intestinal phospholipase B activity in pigs inoculated with transmissible gastroenteritis virus. Am J Vet Res 1985;46:1503-5.

25. Woods RD, Wesley RD, Kapke PA. Neutralization of porcine transmissible gastroenteritis virus by complementdependent monoclonal antibodies. Am J Vet Res 1988;49:300-4.

26. Shepherd RW, Butler DG, Cutz DE, Gall DG, Hamilton JR. The mucosal lesion in viral enteritis.

Gastroenterology 1979;76;770-7.

27. Boosinger TR, Powe TA. Campylobacter jejuni infections in gnotobiotic pigs. Am J Vet Res 1988;49:456-8.

28. Ogilvie BM, Rose E. The response of the host to some parasites of the small intestine: Coccidia and nematodes. Colloq Inst Natl Sante Recherche Med. Immunity in parasitic diseases. 1977;72:237-48.

29. Dunn IJ, Wright KA. The response of the intestinal epithelium in B10.A mice to infection with Trichinella spiralis. J Parasitol 1987;73:712-22.

30. Chen KS. Enzymatic and acidic sensitivity profiles of selected virulent and attenuated transmissible viruses of swine. Am J Vet Res 1985;461:632-6.

31. Burr DH, Caldwell MB, Bourgeois AL, Morgan HR, Wistar R, Walker RI. Mucosal and systemic immunity to Campylobacter jejuni in rabbits after gastric inoculation. Infect Immun 1988;56:99-105.

32. Russell RG, Blaser MJ, Sarmiento JI, Fox J. Experimental Campylobacter jejuni infection in Macaca nemestrina. Infect Immun 1989;51:1438-44.

33. Walker RI, Caldwell MB, Lee EC, Guerry P, Trust TJ, Ruiz-Palacios GM. Pathophysiology of campylobacter enteritis. Microbiol Rev 1986;50:81-94.

34. Blaser MJ, Duncan DJ, Osterholm MT, Istre GR, Wang WL. Serologic study of two clusters of infection due to Campylobacter jejuni. J Infect Dis 1983;147:820-3.

35. Blaser MJ, Black RE, Duncan DJ, Amer J. Campylobacter jejuni-specific serum antibodies are elevated in healthy Bangladeshi children. J Clin Microbiol 1985;21:164-7.
36. Glass RI, Stoll BJ, Huq MI, Struelens MJ, Blaser MJ, Kibriya AK.

Epidemiologic and clinical features of endemic Campylobacter jejuni infection in Bangladesh. J Infect Dis 1983;148:292-6.

37. Melamed I, Bujanover I, Igra YS, Schwartz D, Zakuth V, Spirer S. Campylobacter enteritis in normal and immunodeficient children. Am J Dis Child 1983;137:752-3.

38. Blaser MJ, Reller LB. Campylobacter enteritis. N Engl J Med 1981;305:1444-52.

39. Fox JG, Ackerman JI, Taylor N, Claps M, Murphy JC. Campylobacter jejuni infection in the ferret: An animal model of human campylobacteriosis. Am J Vet Res 1987;48:85-90.

40. Kantele AM, Takanen R, Arvilommi $\mathrm{H}$. Immune response to acute diarrhea seen as circulating antibody-secreting cells. J Infect Dis 1988;158:1011-6.

41. Taylor CE, Bright R. T-cell modulation of the antibody response to bacterial polysaccharide antigens. Infect Immun 1989;57:180-5.

42. Balsih E. Intestinal flora and natural immunity. Microecol Ther 1986;16:157-67.

43. Sneller MC, Strober W. M cells and host defense. J Infect Dis 1986;154:737-41.

44. Wolf JL, Rubin DH, Finberg R, et al. Intestinal $M$ cells: A pathway for entry of reovirus into the host. Science 1981;212:471-2.

45. Owen RL, Pierce NF, Apple RT, Cray WC. M cell transport of Vibrio cholerae from the intestinal lumen into Peyer's patches: A mechanism for antigen sampling and for microbial transepithelial migration. J Infect Dis 1986;153:1108-18.

46. Marcial MA, Madara JL. Cryptosporidium: Cellular localization, structural analysis of absorptive cell-parasite membrane-membrane interactions in guinea-pigs, and suggestion of protozoan transport by $\mathrm{M}$ cells. Gastroenterology 1986;90:583-94.

47. Walker RI, Schmauder-Chock EA, Parker JL. Selective association and transport of Campylobacter jejuni through M cells of rabbit Peyer's patches. Can J Microbiol 1988;34:1142-7.

48. Hugdahl MB, Beery JT, Doyle MP. Chemotactic behaviour of Campylobacter jejuni. Infect Immun 1988;56:1560-6.

49. Sninsky CA, Ramphal R, Gaskins DJ, Goldberg DA, Mathias JR. Alterations of myoelectric activity associated with Campylobacter jejuni and its cell-free filtrate in the small intestine of rabbits. Gastroenterology 1985;89:337-44.
50. Martin PMV, Mathiot J, Ipero J, Kirimat M, Georges AJ, Georges-Courbot M-C. Immune response to Campylobacter jejuni and Campylobacter coli in a cohort of children from birth to 2 years of age. Infect Immun 1989;57:2542-6.

51. Newell DG, McBride H, Dolby JM. Investigations on the role of flagella in the colonization of infant mice with Campylobacter jejuni and attachment of Campylobacter jejuni to human epithelial cell lines. J Hyg Epidemiol Microbiol Immunol 1985;95:217-27.

52. Morooka T, Umeka A, Amako K. Motility as an intestinal colonization factor for Campylobacter jejuni. J Gen Microbiol 1985;131:1973-80.

53. Newell DG. Monoclonal antibodies directed against the flagella of Campylobacter jejuni: Production, characterization and lack of effect on colonization of infant mice. J Hyg Epidemiol Microbiol Immunol 1986;96:131-41.

54. Miller HRP. The protective mucosal response against gastrointestinal nematodes in ruminants and laboratory animals. Vet Immunol Immunopathol 1984;6:167-259.

55. Bell RG, McGregor DD, Despommier DD. Trichinella spiralis: Mediation of the intestinal component of protective immunity in the rat by multiple, phase-specific, antiparasitic responses. Exp Parasitol 1979;47:140-57.

56. Dessein AJ, Parker WL, James SL, David JR. IgE antibody and resistance to infection. I. Selective suppression of the $\lg E$ antibody response in rats diminishes the resistance and the eosinophil response to Trichinella spiralis infection. J Exp Med 1981;153:423-6.

57. Russell DA, Castro GA. Anaphylactic-like reaction of small intestinal epithelium in parasitized guinea-pigs. Immunology $1985 ; 54: 573-9$.

58. Butterworth AE, Taylor DW, Veitch $\mathrm{MC}$, et al. Studies on the mechanisms of immunity in human schistosomiasis. Immunol Rev 1982;61:5-39.

59. Wakelin D, Wilson MM. Immunity to Trichinella spiralis in irradiated mice. Int J Parasitol 1980;10:37-41.

60. Despommier DD, McGregor DD, Crum ED, Carter PB. Immunity to Trichinella spiralis II. Expression of immunity against adult worms. Immunology 1977;33:797-805.

61. Love RJ, Ogilvie BM, McLaren DJ. The immune mechanism which expels the intestinal stage of Trichinella spiralis from rats. Immunology 1976;930:7-15.

62. Wakelin D. Immunity to intestinal parasites. Nature 1978;273:617-20.

63. Crum ED, Despommier DD, McGregor 
DD. Immunity to Trichinella spiralis. I.

Transfer of resistance by two classes of lymphocytes. Immunology 1977;33:787-95.

64. Sun T. Pathology and Clinical Features of Parasitic Diseases. Stoneham: Masson Publishing, 1982:157-62.

65. Hamann KJ, Barker RL, Loegerng DA, Gleich GJ. Comparative toxicity of purified human eosinophil granule proteins for newborn larvae of Trichinella spiralis. J Parasitol 1987;73:513-29.

66. Woodbury RG, Miller HRP, Huntley JF, Newlands GF], Palliser AC, Wakelin D. Mucosal mast cells are functionally active during spontaneous expulsion of intestinal nematode infections in rat. Nature 1984;312:450-2

67. Lee TDG, Sweeter M, Befus AD. Mast cell responses to helminth infection. Parasitol Today 1986;2:186-91.

68. Hessel J, Ramaswamy K, Castro GA. Reduced hexose transport by enterocytes associated with rapid non-injurious rejection of Trichinella spiralis from immune rats. J Parasitol 1982;68:202-13.

69. Woodbury RG, Miller HRP. Quantitative analysis of mucosal mast cell protease in the intestine of Nippostrongylus brasiliensis infected rats. Immunology 1982;46:487-95.

70. Capron A, Dessaint JP, Capron M, Joseph M, Ameisen JC, Tonnel AB. From parasites to allergy: A second receptor for $\lg E$. Immunology 1986;7:15-8.

71. Kawalewsky K, Pachkowski T, Secord DC. Mucinous secretion from canine Heidenhain pouch after stimulation with food, pentagastrin and histamine.
Eur Surg Res 1976;8:536-44.

72. Forstner JF. Intestinal mucins in health and disease. Digestion 1978;17:234-63.

73. Cutz E, Chan W, Track NS, Goth A, Said SI. Release of vasoactive intestinal polypeptide in mast cells by histamine liberators. Nature 1978;275:661-2.

74. Kreijs G], Barkley RM, Read NW, Fordtran JS. Intestinal secretion induced by vasoactive intestinal polypeptide. A comparison with cholera toxin in the canine jejunum in vivo. J Clin Invest 1978;61:1337-45.

75. Luckey TD. Introduction: The villus in chemostat man. Am J Clin Nutr 1974;27:1266-76.

76. Miller HRP. Gastrointestinal mucus, a medium for survival and for elimination of parasitic nematodes aid protozoa. Parasitology 1987;94:S77-100.

77. Alizadeh H, Wakelin D. Comparison of rapid expulsion of Trichinella spiralis in mice and rats. Int J Parasitol 1982;12:65-73.

78. Lee GB, Ogilvie BM. The intestinal mucus barrier to parasites and bacteria. In: Chantler EN, Elder JB, Elstein M, eds. Mucus in Health and Disease. II. Adv Exp Med Biol 1982;144:247-8.

79. Russel DA, Castro GA. Physiological characterization of a biphasic immune response to Trichinella spiralis in the rat. J Infect Dis 1979;139:304-12.

80. Bell RG, McGregor DD, Adams LS. Studies on the inhibition of rapid expulsion of Trichinella spiralis in rats. Int Arch Allergy Appl Immunol 1982;69:73-80.

81. Manson-Smith DF, Bruce RG, Parrott DMV. Villous atrophy and expulsion of intestinal Trichinella spiralis are mediated by T-cells. Cell Immunol
1979;47:285-92.

82. Ferguson A, Jarrett EE.

Hypersensitivity reactions in the small intestine. 1. Thymus dependence of experimental 'partial villous atrophy'. Gut 1975;16:114-7.

83. Erlandsen SL, Chase DG. Morphological alterations in the microvillous border of villous epithelial cells produced by intestinal microorganisms. Am J Clin Nutr 1974;27:1277-86.

84. Buret A, O'Loughlin EV, Curtis G, Gall DG. Effect of acute Yersinia enterocolitica infection on small intestinal ultrastructure. Gastroenterology 1990;98:1401-7.

85. Buret A, Gall DG, Olson ME. Effect of murine giardiasis on growth, intestinal morphology and disaccharidase activity. J Parasitol 1990;76:403-9.

86. Castro GA, Harari Y. Intestinal epithelial membrane changes in rats immune to Trichinella spiralis. Mol Biochem 1982;6:191-204.

87. Castro GA, Badial-Aceves F, Smith JW, Dudrick S], Weisbrodt NW. Altered small bowel propulsion associated with parasitism. Gastroenterology 1976;71:620-5.

88. Wasserman SI. Mediators of immediate hypersensitivity. J Allergy Clin Immunol 1983;72:101-15.

89. Erlandsen SL, Chase DG. Paneth cell function: Phagocytosis and intracellular digestion of intestinal microorganisms. 1. Hexamita muris. J Ultrastruct Res 1972;41:291-301.

90. Erlandsen SL, Chase DG. Paneth cell function: Phagocytosis and intracellular digestion of intestinal microorganisms. II. Spiral microorganisms. J Ultrastruct Res 1972;41:319-30. 


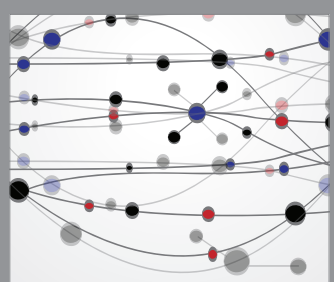

The Scientific World Journal
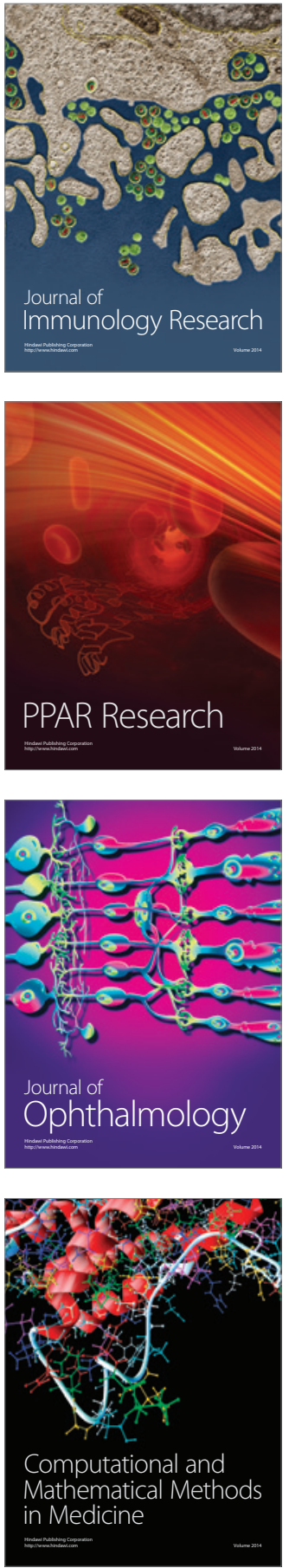

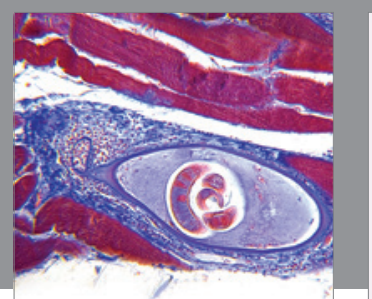

Gastroenterology Research and Practice

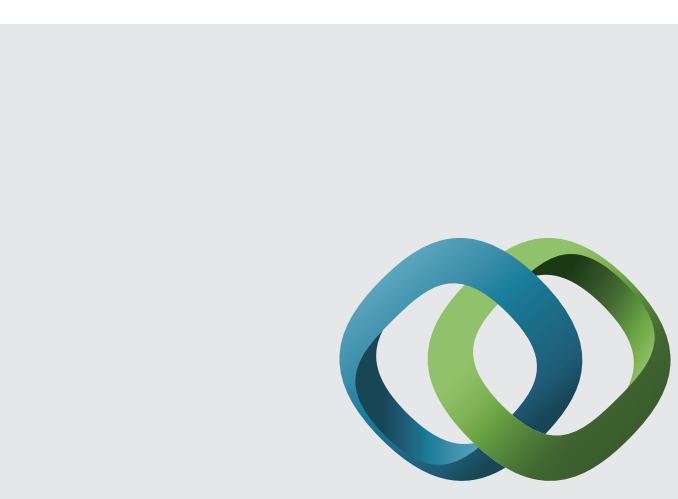

\section{Hindawi}

Submit your manuscripts at

http://www.hindawi.com
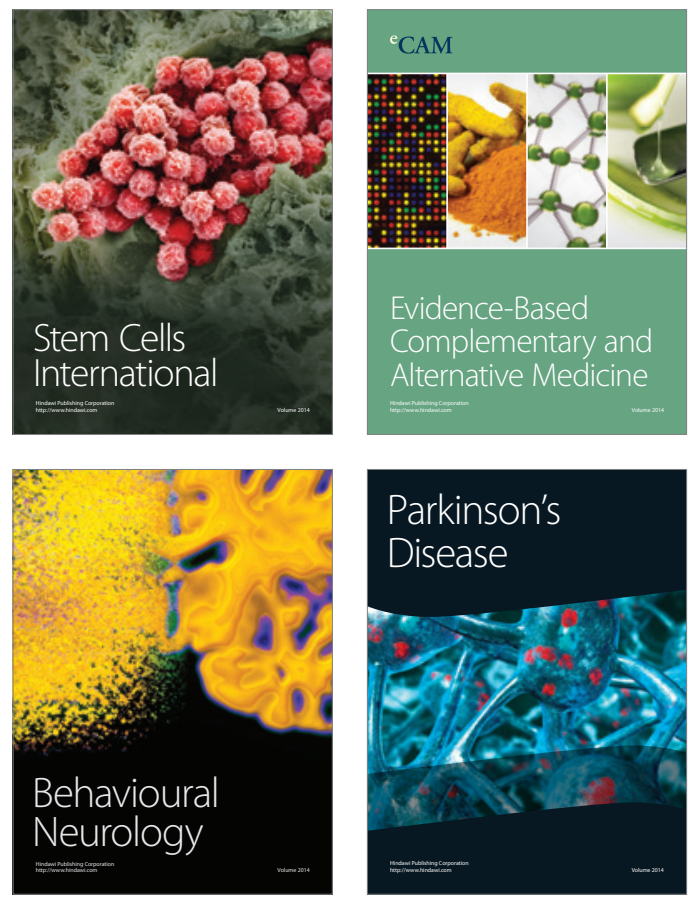
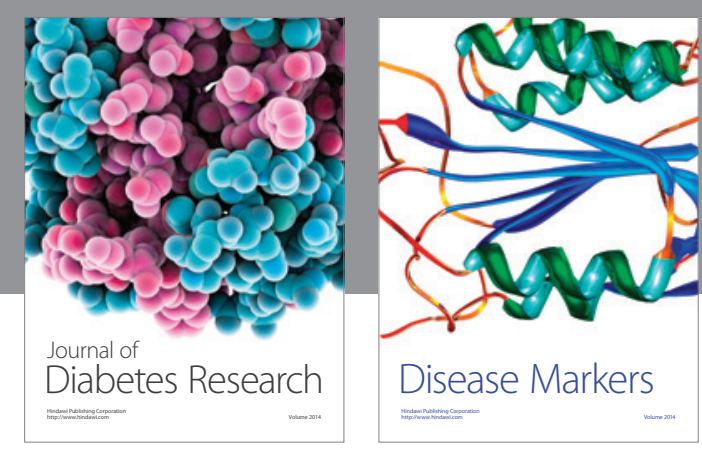

Disease Markers
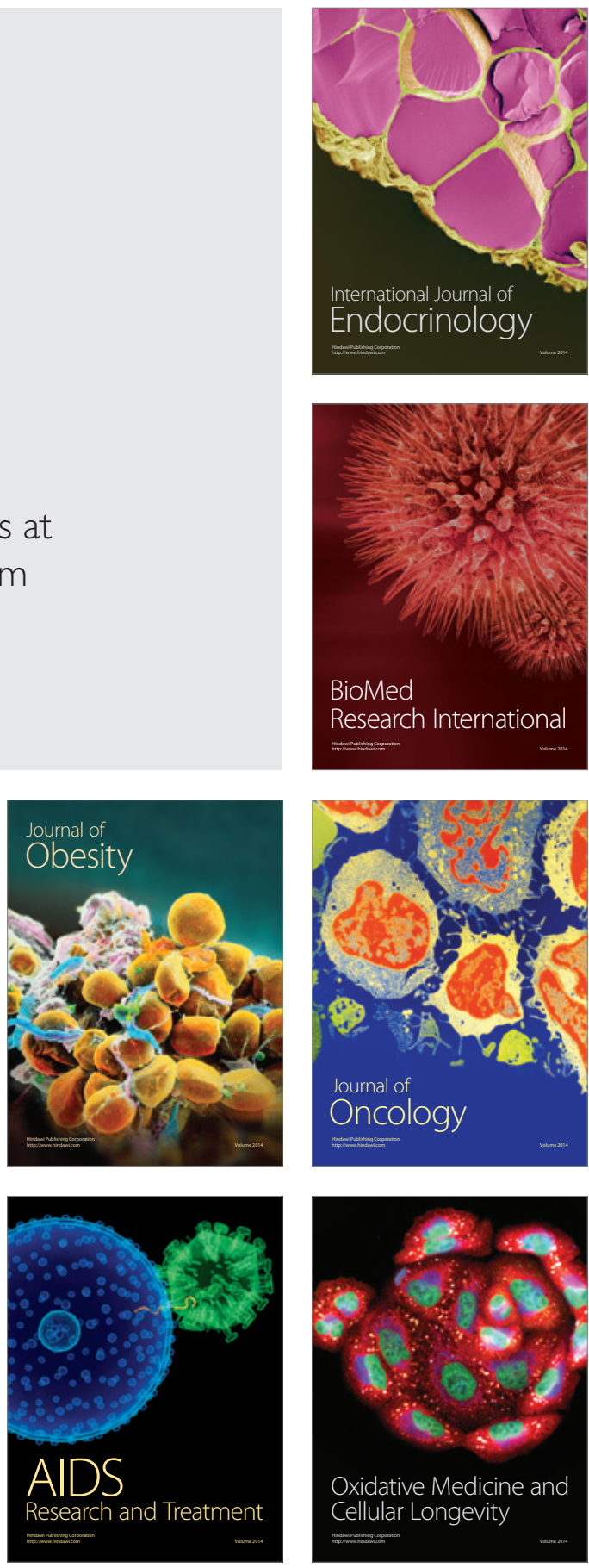